\title{
UJI EFEK ANALGESIK EKSTRAK ETANOL DAUN GEDI (Abelmoschus manihot (L.) Medik) PADA MENCIT (Mus musculus)
}

\author{
${ }^{1}$ Ristanti Pratiwi \\ ${ }^{2}$ Jimmy Posangi \\ ${ }^{3}$ Fatimawali
}

\author{
${ }^{1}$ Kandidat Skripsi Fakultas Kedokteran Universitas Sam Ratulangi \\ ${ }^{2}$ Bagian Farmakologi Dan Terapi Fakultas Kedokteran Universitas Sam ratulangi \\ ${ }^{3}$ Program Studi Farmasi Fakultas MIPA Universitas Sam Ratulangi \\ Email: risutanti_62@yahoo.com
}

\begin{abstract}
The objectives of the research were to find out the analgesic effect of giving Gedi (Abelmoschus manihot (L.) Medik) leaf ethanol extract orally on the number of writhing after thermal pain induction of mice. This research using 15 mice which is divided into 5 groups consisted of 1 negative control group given by the aquades, 1 positive control group given by the tramadol, and 3 experiment groups. Experiment group given by Gedi (Abelmoschus manihot (L.) Medik) leaf ethanol extract with the doses which different each other, that is 30 $\mathrm{mg} / 30 \mathrm{~g} \mathrm{BW}, 60 \mathrm{mg} / 30 \mathrm{~g} \mathrm{BW}$ and $120 \mathrm{mg} / 30 \mathrm{~g} \mathrm{BW}$. Thermal pain induction was done by placing the mice on hot plate constant temperature of $55^{\circ} \mathrm{C}$. The mice gave respond in the way of lick its foot or even jumping. The data was collected using table, graphic and analyzed using one direction ANOVA model and it was continued with LSD test to find out the difference every treatment group. The result of analysis showed that gedi's leaf ethanol extract have the analgesic effect and the maximum effect presented at gedi leaf ethanol extract dosage $60 \mathrm{mg} / 30 \mathrm{~g} \mathrm{BW}$.
\end{abstract}

Keywords: Gedi’s leaf, analgesic effect

\begin{abstract}
Abstrak: Tujuan penelitan ini yaitu menemukan efek analgesik dari pemberian ekstrak etanol daun gedi (Abelmoschus manihot (L.) Medik) peroral pada mencit yang kemudian diamati jumlah geliatnya setelah diinduksi panas. Penelitian ini menggunakan 15 ekor mencit yang dibagi 5 kelompok yang terdiri dari 1 kelompok kontrol negatif yang diberi aquades, 1 kelompok kontrol positif yang diberi tramadol, dan 3 kelompok eksperimen. Kelompok eksperimen diberi ekstrak etanol daun gedi dengan dosis yang berbeda-beda, yaitu $30 \mathrm{mg} / 30 \mathrm{~g}$ $\mathrm{BB}, 60 \mathrm{mg} / 30 \mathrm{~g} \mathrm{BB}$, dan $120 \mathrm{mg} / 30 \mathrm{~g}$ BB. Induksi nyeri berupa panas dilakukan dengan meletakkan mencit pada hot plate dengan suhu $55^{\circ} \mathrm{C}$. Mencit memberi respon berupa menjilat kaki dan atau melompat. Data disajikan berupa tabel, grafik dan menggunakan analisis statistik ANOVA yang dilanjutkan dengan LSD untuk menemukan perbedaan dari setiap kelompok. Hasil analisis menunjukkan bahwa ekstrak etanol daun gedi memiliki efek analgesik dan efek maksimumnya didapatkan pada dosis $60 \mathrm{mg} / 30 \mathrm{~g} \mathrm{BB}$.
\end{abstract}

Kata kunci: Daun gedi, efek analgesik

Indonesia merupakan negara yang kaya dengan bahan alam terutama tumbuhan yang berpotensi besar untuk dimanfaatkan dan dikembangkan secara maksimal. Perubahan sikap kembali ke alam (back to nature) sekarang ini justru membuat pemanfaatan tumbuhan sebagai obat semakin meningkat. Pemanfaatan tanaman tersebut dikenal dengan nama obat herbal yang juga dikenal sebagai phytotherapy, 
jamu, obat botani, atau jamu medis. Obat herbal yaitu suatu bentuk pengobatan alternatif yang mencakup penggunaan tanaman atau ekstrak tanaman. Ini merupakan salah satu pilihan pengobatan yang efektif dan relatif aman, digunakan untuk mengobati penyakit. Selain mengobati, herbal juga sering digunakan untuk pencegahan penyakit atau meningkatkan daya tahan tubuh dari penyakit. ${ }^{1,2}$

Berbagai sayuran memiliki khasiat obat karena mengandung senyawa kimia tertentu. Senyawa kimia ini mempunyai efek farmakologis untuk membantu penyembuhan berbagai jenis penyakit. Gedi (Abelmoschus manihot (L.) Medik) merupakan tumbuhan tropis famili Malvaceae, telah lama dikenal di Sulawesi Utara sebagai tanaman sayuran juga memiliki berbagai khasiat. ${ }^{3,4}$ Pada bagianbagian tanaman gedi (Abelmoschus manihot (L.) Medik) seperti akar, biji, dan bagian yang lain sering digunakan pada pengobatan tradisional yaitu sebagai pengobatan bronkitis kronik, sakit gigi, dan nyeri otot. Daun gedi juga kaya akan vitamin $\mathrm{A}$, Fe, dan serat yang baik untuk pencernaan. Kolagen dalam daun gedi berkhasiat antioksidan dan menjaga kesehatan kulit. Serat daun gedi berkhasiat untuk penyerapan kolesterol dan lemak.,

Berdasarkan informasi di atas, dapat diketahui bahwa tanaman gedi memiliki banyak manfaat, diantaranya yaitu sebagai obat sakit gigi dan nyeri otot. Untuk membuktikan pernyataan tersebut, maka penulis tertarik melakukan penelitian uji efek analgesik dari daun gedi yang dibuat menjadi ekstrak, pada hewan uji mencit (Mus musculus) dengan tramadol sebagai pembanding positif. Penelitian ini diharapkan dapat memberikan informasi kepada masyarakat mengenai efek analgesik yang dimiliki oleh daun gedi, sehingga masyarakat dapat mengetahui secara jelas fungsi daun gedi untuk menghilangkan rasa nyeri. Tujuan penelitan ini yaitu untuk menemukan adanya efek analgesik ekstrak etanol daun gedi (Abelmoschus manihot (L.) Medik) pada mencit (Mus musculus) dengan menggunakan metode rangsang panas.

\section{METODOLOGI PENELITIAN}

Jenis penelitian yang digunakan yaitu penelitian eksperimental. Penelitian dilaksanakan di Laboratorium Farmakologi Fakultas Kedokteran, Laboratorium Farmasetika dan Laboratorium Advance Fakultas MIPA Universitas Sam Ratulangi sejak bulan September 2012 sampai Januari 2013. Penelitian ini menggunakan hewan uji mencit (Mus musculus), berjumlah 15 ekor. Hewan ini dibagi dalam 5 kelompok, yaitu: satu kelompok sebagai kontrol negatif terdiri dari 3 ekor mencit yang diberi aquades, satu kelompok sebagai kontrol positif terdiri dari 3 ekor mencit yang diberi obat analgesik (Tramadol), dan tiga kelompok eksperimen masing-masing 3 ekor mencit yang diberi ekstrak etanol daun gedi dengan dosis yang berbeda pada tiap kelompok. Alat-alat yang digunakan antara lain: water bath (hot plate), beker gelas, evaporator, oven, erlenmeyer, corong, cawan petri, penghitung waktu (stopwatch), timbangan analitik, semprit injeksi $1 \mathrm{ml}$, kertas penyaring Whatman no. 1 dan NGT (Nasogastric Tube) pediatrik no. 3,5. Bahan-bahan yang digunakan antara lain: aquades, daun gedi, obat analgesik (Tramadol) $50 \mathrm{mg}$, dan alkohol $70 \%$. Kemampuan efek analgesik dari ekstrak etanol daun gedi diharapkan dapat memberikan penurunan terhadap respon mencit yaitu menjilat kaki dan atau melompat untuk menghindari nyeri sebagai respon dari rangsang panas yang diberikan.

\section{Prosedur penelitian}

Prosedur penelitian meliputi proses dari pengambilan bahan, pembuatan ekstrak hingga pengujian pada mencit.

\section{Pengambilan bahan}

Bahan yang digunakan adalah daun gedi yang masih muda yang dipetik langsung dari pohonnya, berasal dari Kelurahan Malalayang, Kecamatan Bahu, Kota Manado. 


\section{Ekstraksi Bahan}

Proses ekstraksi bahan dalam penelitian ini menggunakan proses maserasi dengan pelarut alkohol $70 \%$. Langkah-langkah metode maserasi yaitu: daun gedi yang yang telah diambil dibersihkan, kemudian di keringkan dengan suhu ruangan dan dikeringkan dalam oven dengan suhu $39^{\circ} \mathrm{C}$. Daun gedi yang telah dikeringkan kemudian dihaluskan dengan blender menjadi tepung daun gedi. Tepung daun gedi ditimbang sebanyak 100 gram, kemudian direndam dengan alkohol 70\% sebanyak $1000 \mathrm{ml}$ selama 5 hari. Selama perendaman, setiap hari diaduk selama 15 menit. Setelah direndam selama 5 hari, kemudian disaring dengan menggunakan kertas saring Whatman no. 1. Hasil penyaringan kemudian ditempatkan dalam erlenmeyer untuk diuapkan alkoholnya dengan evaporator. Hasilnya diletakkan cawan petri dan diuapkan dalam oven dengan suhu $39^{\circ} \mathrm{C}$ sampai didapatkan hasil ekstrak. Ekstrak inilah yang digunakan dalam penelitian.

\section{Persiapan hewan uji}

Hewan uji yang digunakan yaitu mencit (Mus musculus). Mencit yang akan digunakan yakni mencit betina yang memiliki berat badan sekitar 20-30 gram. Mencit dipuasakan selama \pm 11 jam sebelum perlakuan. Mencit dibagi secara acak ke dalam 5 kelompok yaitu: kelompok kontrol negatif, kelompok kontrol positif, kelompok eksperimen yang diberi ekstrak etanol daun gedi dengan dosis $30 \mathrm{mg} / 30 \mathrm{~g}$ $\mathrm{BB}$, kelompok eksperimen yang diberi ekstrak etanol daun gedi dengan dosis 60 mg/30 g BB, dan kelompok eksperimen yang diberi ekstrak etanol daun gedi dengan dosis 120 mg/30 g BB.

\section{Persiapan bahan uji ekstrak etanol daun gedi}

Kelompok mencit yang diberi ekstrak etanol daun gedi dengan dosis $30 \mathrm{mg} / 30 \mathrm{~g}$ BB yaitu ekstrak diambil sebanyak $100 \mathrm{mg}$ kemudian ditambahkan $1 \mathrm{ml}$ aquades. Kelompok mencit yang diberi ekstrak etanol daun gedi dengan dosis $60 \mathrm{mg} / 30 \mathrm{~g}$ BB yaitu ekstrak diambil sebanyak $200 \mathrm{mg}$ kemudian ditambahkan $1 \mathrm{ml}$ aquades. Kelompok mencit yang diberi ekstrak etanol daun gedi dengan dosis $120 \mathrm{mg} / 30 \mathrm{~g}$ BB yaitu ekstrak diambil sebanyak $400 \mathrm{mg}$ kemudian ditambahkan $1 \mathrm{ml}$ aquades. Ambil 0,3 ml larutan ekstrak etanol daun gedi tersebut untuk diberikan pada kelompok hewan eksperimen.

\section{Persiapan bahan uji kontrol positif (tramadol)}

Dosis tramadol yang biasa digunakan yaitu 50-400 mg per hari. Dosis tramadol yang akan digunakan yaitu $100 \mathrm{mg}$. Dosis diberikan disetarakan dengan dosis pada manusia dengan berat badan $70 \mathrm{~kg}$ ke mencit 20 gram dikalikan dengan konstanta uji terapi pada hewan coba (mencit) yaitu 0,0026 (Laurence \& Bacharach, 1964). Jadi perhitungan dosis konversi yang diberikan pada kelompok kontrol positif yaitu: dosis untuk mencit 20 gram $=0,0026 \times 100 \mathrm{mg}$ $=0,26 \mathrm{mg} / 20 \mathrm{~g} \mathrm{BB}$ mencit. 50/70 x 0,26 $\mathrm{mg}=0,18 \mathrm{mg} / 20 \mathrm{~g}$ BB mencit, maka dosis tramadol untuk mencit yaitu $0,18 \mathrm{mg}$ yang kemudian dilarutkan dengan aquades sampai mencapai $0,3 \mathrm{ml}$.

\section{Persiapan bahan uji kontrol negatif (aquades)}

Aquades diambil 0,3 ml kemudian diberikan pada tiap hewan uji kontrol negatif.

\section{Cara pemberian bahan uji}

Pemberian bahan uji yaitu ekstrak etanol daun gedi, aquades, dan tramadol dilakukan peroral menggunakan semprit 1 ml dan NGT (Nasogastric Tube) pediatrik no. 3,5 .

\section{Pengujian efek analgesik}

Langkah-langkah pengujian efek analgesik pada hewan uji yaitu: beker gelas ditempatkan di atas water bath (hot plate), kemudian dipanaskan hingga suhu $55^{\circ} \mathrm{C}$. Setelah suhu mencapai $55^{\circ} \mathrm{C}$, mencit dimasukkan ke dalam beker gelas tersebut. 
Pengamatan respon mencit sebelum pemberian bahan uji setelah diberikan rangsangan panas, yaitu respon menjilat kaki dan atau melompat untuk menghindari nyeri selama 1 menit, kemudian diberikan bahan uji kepada tiap mencit masingmasing kelompok yang akan diuji. Pengamatan terhadap respon mencit terhadap rangsangan panas setelah pemberian bahan uji pada masing-masing kelompok pada menit ke-30, 60, 90, dan 120. Pengamatan dilakukan selama 1 menit. Total pengamatan dilakukan sebanyak 5 kali, yaitu: sebelum pemberian bahan uji, menit ke-30, 60, 90, dan 120 setelah pemberian bahan uji.

\section{Analisis data}

Data hasil pengamatan dikumpulkan dan disajikan dalam bentuk tabel, grafik dan analisis statistik uji ANOVA (Analysis Of Variance).

\section{HASIL PENELITIAN}

Data hasil penelitian berikut merupakan data yang didapatkan dari 5 kelompok hewan uji yang masing-masing kelompok terdiri dari 3 ekor mencit, sebagai berikut:

\section{Kelompok kontrol negatif}

Dari hasil pengamatan yang didapatkan pada kelompok kontrol negatif dengan pemberian aquades dapat dilihat pada Tabel 1.

Pada Tabel 1 terlihat rata-rata respon mencit sebelum pemberian aquades yaitu 54 kali, kemudian setelah pemberian aquades terlihat kenaikan dan penurunan rata-rata respon mencit namun tidak terlalu jauh perbedaannya dari sebelum dan setelah pemberian aquades pada menit ke 30, 60, 90 dan 120.

\section{Kelompok kontrol positif}

Dari hasil pengamatan yang didapatkan dari kelompok kontrol positif dengan pemberian tramadol dapat dilihat pada Tabel 2.

Pada Tabel 2 terlihat sebelum pemberian tramadol rata-rata jumlah respon mencit yaitu 57 kali. Efek analgesik mulai terlihat dari penurunan rata-rata respon mencit setelah pemberian tramadol menit ke-30 menjadi 45 kali, kemudian terus menurun pada menit ke-60 yaitu 44 kali. Penurunan respon mencit terus turun pada menit ke-90 yaitu 37 kali dan terus turun pada menit ke-120 yaitu 35 kali. Penurunan respon mencit dari sebelum pemberian tramadol sampai setelah pemberian tramadol hingga menit ke-120 menandakan adanya efek analgesik.

Tabel 1. Hasil pengamatan respon mencit kelompok kontrol negatif (aquades)

\begin{tabular}{|c|c|c|c|c|c|c|c|c|c|c|c|c|c|c|c|}
\hline \multirow{4}{*}{ Kelompok } & \multicolumn{15}{|c|}{ Waktu } \\
\hline & \multirow{2}{*}{\multicolumn{3}{|c|}{$\begin{array}{c}\text { Sebelum } \\
\text { Perlakuan }\end{array}$}} & \multicolumn{12}{|c|}{ Setelah perlakuan } \\
\hline & & & & \multicolumn{3}{|c|}{$30 \prime$} & \multicolumn{3}{|c|}{$60^{\prime}$} & \multicolumn{3}{|c|}{$90^{\prime}$} & \multicolumn{3}{|c|}{ 120' } \\
\hline & $\mathrm{L}$ & $\mathrm{J}$ & $\mathrm{T}$ & $\mathrm{L}$ & $\mathrm{J}$ & $\mathrm{T}$ & $\mathrm{L}$ & $\mathrm{J}$ & $\mathrm{T}$ & $\mathrm{L}$ & $\mathrm{J}$ & $\mathrm{T}$ & $\mathrm{L}$ & $\mathrm{J}$ & $\mathrm{T}$ \\
\hline Mencit I & - & 71 & 71 & - & 68 & 68 & - & 36 & 36 & - & 56 & 56 & - & 53 & 53 \\
\hline Mencit II & 4 & 43 & 47 & 15 & 34 & 49 & 2 & 81 & 83 & 1 & 54 & 55 & - & 59 & 59 \\
\hline Mencit III & 2 & 42 & 44 & - & 86 & 86 & - & 88 & 88 & - & 60 & 60 & - & 71 & 71 \\
\hline Jumlah & & & 162 & & & 203 & & & 207 & & & 171 & & & 183 \\
\hline Rata-rata & & & 54 & & & 68 & & & 69 & & & 57 & & & 61 \\
\hline
\end{tabular}

Ket : $\mathrm{L}=$ Lompat; $\mathrm{J}=$ Jilat; $\mathrm{T}=$ Total

*Pembulatan bilangan desimal $<0,5=0$ dan $\geq 0,5=1$ 
Tabel 2. Hasil pengamatan respon mencit kelompok kontrol positif (tramadol)

\begin{tabular}{|c|c|c|c|c|c|c|c|c|c|c|c|c|c|c|c|}
\hline \multirow{4}{*}{ Kelompok } & \multicolumn{15}{|c|}{ Waktu } \\
\hline & \multirow{2}{*}{\multicolumn{3}{|c|}{$\begin{array}{c}\text { Sebelum } \\
\text { Perlakuan }\end{array}$}} & \multicolumn{12}{|c|}{ Setelah perlakuan } \\
\hline & & & & \multicolumn{3}{|c|}{$30 \prime$} & \multicolumn{3}{|c|}{ 60' } & \multicolumn{3}{|c|}{ 90' } & \multicolumn{3}{|c|}{ 120' } \\
\hline & $\mathrm{L}$ & $\mathrm{J}$ & $\mathrm{T}$ & $\mathrm{L}$ & $\mathrm{J}$ & $\mathrm{T}$ & $\mathrm{L}$ & $\mathrm{J}$ & $\mathrm{T}$ & $\mathrm{L}$ & $\mathrm{J}$ & $\mathrm{T}$ & $\mathrm{L}$ & $\mathrm{J}$ & $\mathrm{T}$ \\
\hline Mencit I & - & 51 & 51 & 2 & 15 & 17 & 1 & 35 & 36 & - & 33 & 33 & 11 & 9 & 20 \\
\hline Mencit II & - & 69 & 69 & - & 65 & 65 & - & 59 & 59 & - & 55 & 55 & - & 60 & 60 \\
\hline Mencit III & - & 51 & 51 & - & 53 & 53 & - & 37 & 37 & - & 24 & 24 & - & 25 & 25 \\
\hline Jumlah & & & 171 & & & 135 & & & 132 & & & 112 & & & 105 \\
\hline Rata-rata & & & 57 & & & 45 & & & 44 & & & $37 *$ & & & 35 \\
\hline
\end{tabular}

Ket : $\mathrm{L}=$ Lompat; $\mathrm{J}=$ Jilat; $\mathrm{T}=$ Total

$*$ Pembulatan bilangan desimal $<0,5=0$ dan $\geq 0,5=1$

Tabel 3. Hasil pengamatan respon mencit kelompok kontrol eksperimen ekstrak etanol daun gedi dosis $30 \mathrm{mg} / 30 \mathrm{~g} \mathrm{BB}$

\begin{tabular}{|c|c|c|c|c|c|c|c|c|c|c|c|c|c|c|c|}
\hline \multirow{4}{*}{ Kelompok } & \multicolumn{15}{|c|}{ Waktu } \\
\hline & \multicolumn{3}{|c|}{ Sebelum } & \multicolumn{12}{|c|}{ Setelah perlakuan } \\
\hline & \multicolumn{3}{|c|}{ Perlakuan } & \multicolumn{3}{|c|}{$30^{\prime}$} & \multicolumn{3}{|c|}{$60^{\prime}$} & \multicolumn{3}{|c|}{$90^{\prime}$} & \multicolumn{3}{|c|}{$120^{\prime}$} \\
\hline & $\mathrm{L}$ & $\mathrm{J}$ & $\mathrm{T}$ & $\mathrm{L}$ & $\mathrm{J}$ & $\mathrm{T}$ & $\mathrm{L}$ & $\mathrm{J}$ & $\mathrm{T}$ & $\mathrm{L}$ & $\mathrm{J}$ & $\mathrm{T}$ & $\mathrm{L}$ & $\mathrm{J}$ & $\mathrm{T}$ \\
\hline Mencit I & 1 & 34 & 35 & - & 45 & 45 & - & 20 & 20 & - & 22 & 22 & - & 35 & 35 \\
\hline Mencit II & - & 73 & 73 & 16 & - & 16 & 4 & 24 & 28 & - & 33 & 33 & 2 & 18 & 20 \\
\hline Mencit III & 3 & 30 & 33 & - & 58 & 58 & - & 47 & 47 & - & 42 & 42 & - & 60 & 60 \\
\hline Jumlah & & & 141 & & & 119 & & & 95 & & & 97 & & & 115 \\
\hline Rata-rata & & & 47 & & & $40 *$ & & & $32 *$ & & & $32 *$ & & & $38 *$ \\
\hline
\end{tabular}

Ket : L = Lompat; $\mathrm{J}=$ Jilat; $\mathrm{T}=$ Total

*Pembulatan bilangan desimal $<0,5=0$ dan $\geq 0,5=1$

\section{Kelompok eksperimen ekstrak etanol daun gedi dosis $30 \mathrm{mg} / 30 \mathrm{~g} \mathrm{BB}$}

Dari hasil pengamatan yang didapatkan dari kelompok eksperimen yang diberi ekstrak etanol daun gedi dengan dosis $30 \mathrm{mg} / 30 \mathrm{~g}$ BB dapat dilihat pada Tabel 3.

Pada Tabel 3 terlihat rata-rata respon mencit sebelum pemberian ekstrak etanol daun gedi yaitu 47 kali. Adanya efek analgesik ekstrak etanol daun gedi dosis 30 $\mathrm{mg} / 30 \mathrm{~g}$ BB terlihat setelah pemberian ekstrak etanol daun gedi yaitu terjadi penurunan rata-rata respon mencit pada menit ke-30 dan menit ke-60 menjadi 40 kali dan 32 kali. Efek analgesik ekstrak etanol daun gedi dosis $30 \mathrm{mg} / 30 \mathrm{~g} \mathrm{BB}$ menetap dengan rata-rata respon mencit pada menit ke-90 yaitu 32 kali dan rata-rata respon mencit sedikit meningkat pada menit ke-120 yaitu 38 kali, namun efek analgesik ekstrak etanol daun gedi tetap terlihat.

\section{Kelompok eksperimen ekstrak etanol daun gedi dosis $60 \mathrm{mg} / 30 \mathrm{~g}$ BB}

Dari hasil pengamatan yang didapatkan dari kelompok eksperimen yang diberi ekstrak etanol daun gedi dengan dosis $60 \mathrm{mg} / 30 \mathrm{~g}$ BB dapat dilihat pada Tabel 4. 
Tabel 4. Hasil pengamatan respon mencit kelompok kontrol eksperimen ekstrak etanol daun gedi dosis $60 \mathrm{mg} / 30 \mathrm{~g}$ BB

\begin{tabular}{|c|c|c|c|c|c|c|c|c|c|c|c|c|c|c|c|}
\hline \multirow{4}{*}{ Kelompok } & \multicolumn{15}{|c|}{ Waktu } \\
\hline & \multirow{2}{*}{\multicolumn{3}{|c|}{$\begin{array}{c}\text { Sebelum } \\
\text { Perlakuan }\end{array}$}} & \multicolumn{12}{|c|}{ Setelah perlakuan } \\
\hline & & & & \multicolumn{3}{|c|}{$30^{\prime}$} & \multicolumn{3}{|c|}{$60^{\prime}$} & \multicolumn{3}{|c|}{$90^{\prime}$} & \multicolumn{3}{|c|}{$120^{\prime}$} \\
\hline & $\mathrm{L}$ & $\mathrm{J}$ & $\mathrm{T}$ & $\mathrm{L}$ & $\mathrm{J}$ & $\mathrm{T}$ & $\mathrm{L}$ & $\mathrm{J}$ & $\mathrm{T}$ & $\mathrm{L}$ & $\mathrm{J}$ & $\mathrm{T}$ & $\mathrm{L}$ & $\mathrm{J}$ & $\mathrm{T}$ \\
\hline Mencit I & - & 74 & 74 & - & 45 & 45 & - & 49 & 49 & - & 40 & 40 & - & 20 & 20 \\
\hline Mencit II & - & 104 & 104 & - & 73 & 73 & - & 56 & 56 & - & 57 & 57 & - & 43 & 43 \\
\hline Mencit III & - & 34 & 34 & 6 & - & 6 & 6 & - & 6 & 13 & - & 13 & - & - & 0 \\
\hline Jumlah & & & 212 & & & 124 & & & 111 & & & 110 & & & 63 \\
\hline Rata-rata & & & $71 *$ & & & $41 *$ & & & 37 & & & $37 *$ & & & 21 \\
\hline
\end{tabular}

Ket : L = Lompat; $\mathrm{J}=$ Jilat; $\mathrm{T}=$ Total

*Pembulatan bilangan desimal $<0,5=0$ dan $\geq 0,5=1$

Pada Tabel 4 terlihat rata-rata respon mencit sebelum pemberian ekstrak etanol daun gedi dosis $60 \mathrm{mg} / 30 \mathrm{~g}$ BB yaitu 71 kali. Adanya efek analgesik ekstrak etanol daun gedi dosis $60 \mathrm{mg} / 30 \mathrm{~g}$ BB terlihat setelah pemberian ekstrak etanol daun gedi dosis $60 \mathrm{mg} / 30 \mathrm{~g}$ BB yaitu terjadi penurunan rata-rata respon mencit pada menit ke-30 dan menit ke-60 menjadi 41 kali dan 37 kali. Efek analgesik ekstrak etanol daun gedi dosis $60 \mathrm{mg} / 30 \mathrm{~g}$ BB menetap pada menit ke-90 yaitu 37 kali dan kembali terjadi penurunan rata-rata respon mencit pada menit ke-120 yaitu 21 kali. Ini menunjukkan bahwa ekstrak etanol daun gedi dosis $60 \mathrm{mg} / 30 \mathrm{~g}$ BB memiliki efek analgesik.

\section{Kelompok eksperimen ekstrak etanol daun gedi dosis $120 \mathrm{mg} / 30 \mathrm{~g}$ BB}

Dari hasil pengamatan yang didapatkan dari kelompok eksperimen yang diberi ekstrak etanol daun gedi dengan dosis $120 \mathrm{mg} / 30 \mathrm{~g} \mathrm{BB}$ dapat dilihat pada Tabel 5.

Pada Tabel 5 terlihat rata-rata respon mencit sebelum pemberian ekstrak etanol daun gedi yaitu 44 kali. Adanya efek analgesik ekstrak etanol daun gedi terlihat setelah pemberian ekstrak etanol daun gedi yaitu terjadi penurunan rata-rata respon mencit pada menit ke-30 yaitu 22 kali. Efek analgesik ekstrak etanol daun gedi menurun dengan rata-rata respon mencit yang meningkat pada menit ke-60 dan menit ke90 yaitu 36 kali dan 53 kali. Rata-rata respon mencit semakin meningkat pada menit ke-120 yaitu 56 kali. Ini menunjukkan bahwa ekstrak etanol daun gedi dosis $120 \mathrm{mg} / 30 \mathrm{~g}$ BB memiliki efek analgesik pada menit ke-30 dan cepat menghilang saat menit berikutnya.

Data hasil kelompok kontrol negatif, kelompok kontrol positif dan kelompok eksperimen ekstrak etanol daun gedi yang telah dijelaskan sebelumnya pada Tabel 1 , 2, 3, 4 dan 5 menunjukkan perbedaan hasil yaitu kelompok kontrol negatif yang tidak memiliki efek analgesik dan kelompok kontol positif serta kelompok eksperimen ekstrak etanol daun gedi yang memiliki efek analgesik. Hasil pengujian analisis statistik ANOVA terhadap kelompok tersebut juga menunjukkan hasil yang bermakna dengan nilai $p=0,032(p<\alpha)$ dan hasil uji LSD (Least Significant Difference) yang menunjukkan perbedaan yang signifikan antara kelompok kontrol negatif dibandingkan dengan kelompok kontrol positif dan kelompok eksperimen ekstrak etanol daun gedi (Tabel 7).

Pada Tabel 7 menunjukkan bahwa secara statistik perbandingan kelompok kontrol negatif dengan kelompok kontrol positif dan kelompok eksperimen memiliki perbedaan yang signifikan.

Perbandingan rata-rata respon mencit tiap kelompok dapat dilihat pada Gambar 1. 

Tabel 5. Hasil pengamatan respon mencit kelompok kontrol eksperimen ekstrak etanol daun gedi dosis $120 \mathrm{mg} / 30 \mathrm{~g} \mathrm{BB}$

\begin{tabular}{|c|c|c|c|c|c|c|c|c|c|c|c|c|c|c|c|}
\hline \multirow{4}{*}{ Kelompok } & \multicolumn{15}{|c|}{ Waktu } \\
\hline & \multirow{2}{*}{\multicolumn{3}{|c|}{$\begin{array}{c}\text { Sebelum } \\
\text { Perlakuan }\end{array}$}} & \multicolumn{12}{|c|}{ Setelah perlakuan } \\
\hline & & & & \multicolumn{3}{|c|}{$30^{\prime}$} & \multicolumn{3}{|c|}{$60^{\prime}$} & \multicolumn{3}{|c|}{$90^{\prime}$} & \multicolumn{3}{|c|}{$120^{\prime}$} \\
\hline & $\mathrm{L}$ & $\mathrm{J}$ & $\mathrm{T}$ & $\mathrm{L}$ & $\mathrm{J}$ & $\mathrm{T}$ & $\mathrm{L}$ & $\mathrm{J}$ & $\mathrm{T}$ & $\mathrm{L}$ & $\mathrm{J}$ & $\mathrm{T}$ & $\mathrm{L}$ & $\mathrm{J}$ & $\mathrm{T}$ \\
\hline Mencit I & - & 40 & 40 & 6 & - & 6 & 1 & 20 & 21 & 3 & 29 & 32 & - & 38 & 38 \\
\hline Mencit II & 2 & 53 & 55 & - & 44 & 44 & 1 & 51 & 52 & - & 73 & 73 & - & 77 & 77 \\
\hline Mencit III & 6 & 31 & 37 & 2 & 15 & 17 & 1 & 33 & 34 & - & 53 & 53 & - & 54 & 54 \\
\hline Jumlah & & & 132 & & & 67 & & & 107 & & & 158 & & & 169 \\
\hline Rata-rata & & & 44 & & & $22 *$ & & & $36 *$ & & & $53 *$ & & & $56^{*}$ \\
\hline
\end{tabular}

Ket : L = Lompat; $\mathrm{J}=$ Jilat; $\mathrm{T}=$ Total

*Pembulatan bilangan desimal $<0,5=0$ dan $\geq 0,5=1$

Tabel 7. Hasil uji LSD rata-rata total respon mencit kelompok kontrol negatif dibandingkan dengan kelompok kontrol positif dan kelompok eksperimen

\begin{tabular}{lll}
\hline & & P (Signifikan) \\
\hline Kontrol Negatif & Kontrol Positif & 0,023 \\
& Gedi Dosis $30 \mathrm{mg} / 30 \mathrm{~g}$ BB & 0,004 \\
& Gedi Dosis $60 \mathrm{mg} / 30 \mathrm{~g}$ BB & 0,012 \\
& Gedi Dosis $120 \mathrm{mg} / 30 \mathrm{~g} \mathrm{BB}$ & 0,015 \\
\hline
\end{tabular}

Keterangan : $\alpha=0,05$

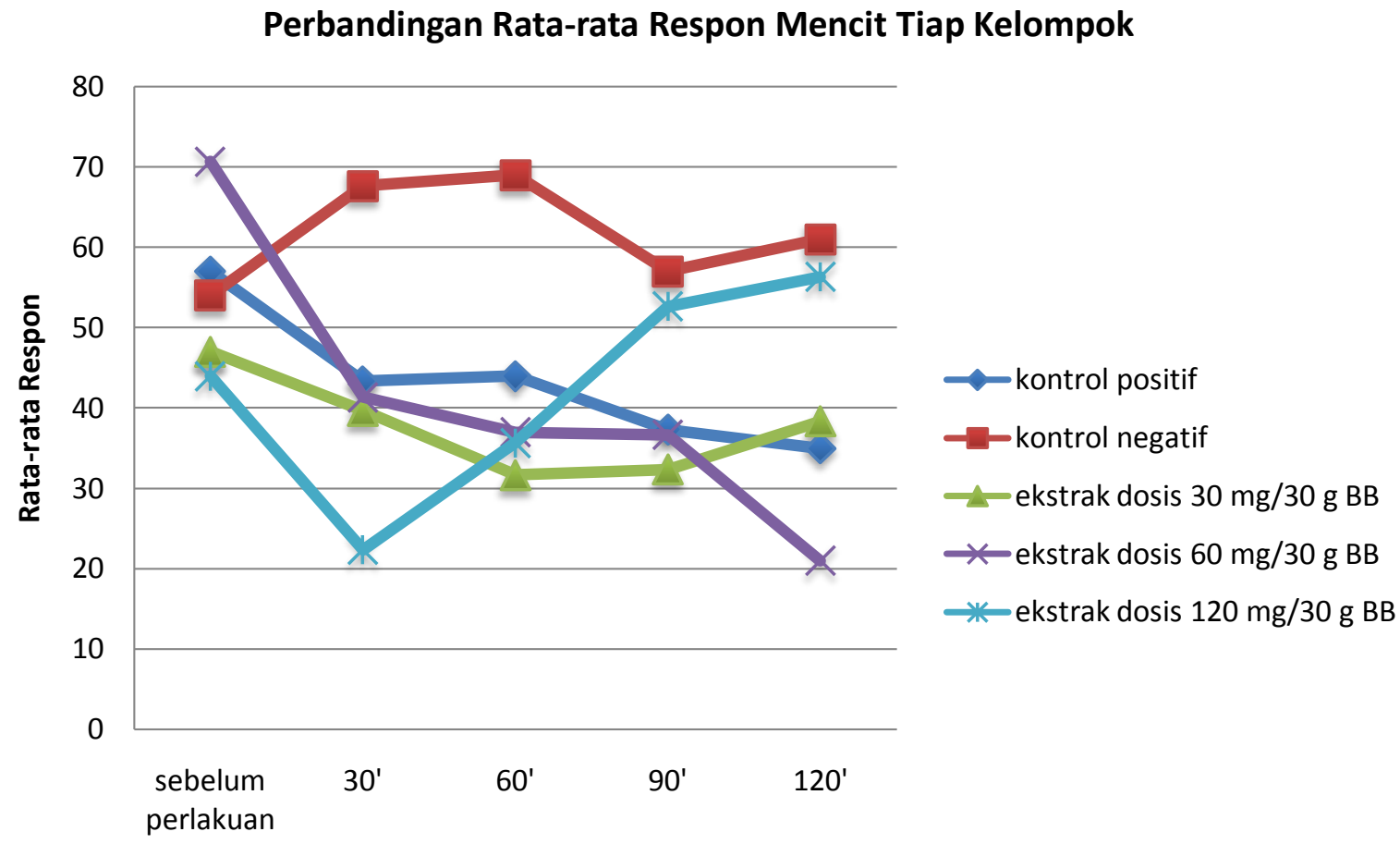

Waktu (menit ke-)

Gambar 1. Grafik perbandingan rata-rata respon mencit tiap kelompok 
Pada grafik terlihat bahwa rata-rata respon mencit kelompok kontrol positif dan kelompok ekstrak etanol daun gedi mengalami penurunan setelah perlakuan dibandingkan sebelum perlakuan, sedangkan rata-rata respon mencit kelompok kontrol negatif cenderung stabil.

\section{BAHASAN}

Hasil penelitian yang didapatkan pada 3 kelompok mencit perlakuan eksperimen yang diberikan ekstrak etanol daun gedi terlihat penurunan rata-rata respon nyeri dari mencit sebelum perlakuan dibandingkan setelah perlakuan. Penurunan rata-rata respon nyeri dari mencit ini menunjukkan adanya efek analgesik dari ekstrak etanol daun gedi.

Berdasarkan kelompok eksperimen ekstrak yang diuji, ekstrak etanol daun gedi dosis $60 \mathrm{mg} / 30 \mathrm{~g}$ BB menghasilkan efek analgesik yang lebih baik dibandingkan dengan ekstrak etanol daun gedi dosis 30 $\mathrm{mg} / 30 \mathrm{~g}$ BB dan dosis $120 \mathrm{mg} / 30 \mathrm{~g}$ BB. Tanpa melihat perbedaan dosis ekstrak etanol daun gedi yang memiliki efek analgesik, penelitian ini membuktikan secara farmakologis bahwa tumbuhan ini memiliki efek analgesik. Berdasarkan studi literatur, didapatkan bahwa diduga steroid, triterpenoid, dan flavonoid yang terkandung dalam daun tumbuhan gedi (Abelmocshus manihot (L.) Medik) memiliki efek analgesik.,

Pada kelompok eksperimen ekstrak etanol daun gedi dosis $120 \mathrm{mg} / 30 \mathrm{~g}$ BB didapatkan hasil yang sulit dievaluasi bisa dikarenakan dosis yang telah melebihi dosis maksimum dari ekstrak etanol daun gedi. Berdasarkan studi literatur, bahwa dosis percobaan maksimum dari ekstrak etanol yang ditoleransi untuk hewan yaitu 2000 mg/KgBB. ${ }^{6,7}$ Pada kelompok eksperimen ekstrak gedi dosis $120 \mathrm{mg} / 30 \mathrm{~g}$ $\mathrm{BB}$ setara dengan dosis $4000 \mathrm{mg} / \mathrm{kg} \mathrm{BB}$, maka dosis ini sudah melebihi dari dosis 2000 mg/KgBB. Karena banyaknya zat-zat fitokimia yang terkandung yang diberikan pada hewan coba menyebabkan efek analgesik dari ekstrak etanol daun gedi dosis $120 \mathrm{mg} / 30 \mathrm{~g}$ BB sulit dievaluasi. Kemungkinan salah satu zat fitokimia tersebut yaitu Quercetin yang merupakan salah satu fitokimia yang terisolasi dalam flavonoid, jika terlalu banyak di dalam tubuh akan mengakibatkan reaksi alergi, mual, muntah, sakit kepala, dan nyeri sendi. ${ }^{8,9}$

Dari hasil pengamatan terhadap kelompok kontrol positif yakni tramadol, efek analgesik tramadol pada mencit mulai terlihat pada menit ke-30 setelah pemberian tramadol dimana terjadi penurunan jumlah rata-rata respon nyeri dari mencit terhadap rangsang panas. Efek analgesik tramadol tetap terlihat sampai akhir pengujian pada menit ke-120. Efek analgesik tramadol mencapai puncak pada menit ke-120.

Pada manusia, efek analgesik tramadol timbul pada 1 jam setelah penggunaan secara oral dan mencapai puncak pada 2-3 jam. Berdasarkan penelitian pada kontrol positif, efek analgesik tramadol pada mencit timbul pada menit ke-30 setelah pemberian oral dan puncaknya pada menit ke-120. Hal ini mungkin terjadi karena faktor perbedaan spesies antara manusia dengan mencit yakni perbedaan metabolisme mencit dan manusia, namun untuk efek analgesik puncaknya sesuai dengan teori yang mengatakan bahwa efek analgesik tramadol mencapai puncak dalam 2-3 jam. ${ }^{10}$

Dari keseluruhan data yang didapatkan dari kelompok eksperimen memperlihatkan bahwa efek yang ditimbulkan oleh ekstrak etanol daun gedi dosis $60 \mathrm{mg} / 30 \mathrm{~g}$ BB sedikit lebih baik daripada tramadol, pada mencit. Hal ini kemungkinan disebabkan oleh perbedaan dosis yang diberikan dimana dosis ekstrak etanol daun gedi dosis $60 \mathrm{mg} / 30 \mathrm{~g}$ BB (dalam penelitian ini setara dengan dosis $2000 \mathrm{mg} / \mathrm{KgBB}$ atau dosis maksimum untuk pengujian ekstrak) lebih besar daripada dosis tramadol. Pemberian dosis yang tinggi dari ekstrak etanol daun gedi ini dimaksudkan untuk mendapat efek analgesik yang lebih pasti dari ekstrak etanol daun gedi pada mencit.

Data hasil pengamatan yang didapatkan dari kelompok kontrol negatif 
yaitu aquades memperlihatkan bahwa ratarata respon nyeri dari mencit sebelum pemberian aquades dan setelahnya, tidak menunjukkan adanya perbedaan rata-rata respon mencit setiap 30 menit dan cenderung stabil sampai menit ke-120, sehingga dapat disimpulkan bahwa aquades tidak memiliki efek analgesik.

Dari hasil pengamatan data yang telah dilakukan terhadap mencit yang diinduksi dengan panas pada water bath (hot plate), terlihat bahwa tidak semua mencit menunjukkan respon yang sama. Ketidaksamaan tersebut antara lain, ada yang memberikan respon lompatan atau hanya berupa jilatan atau keduanya dan jumlah respon mencit yang berbeda-beda sebelum perlakuan. Hal ini kemungkinan disebabkan oleh banyaknya faktor yang mempengaruhi perbedaan respon mencit tersebut.

Faktor yang mempengaruhi perbedaan respon mencit bisa dari eksternal dan internal. Faktor eksternal antara lain yaitu suhu hot plate yang tidak tepat pada suhu $55^{\circ} \mathrm{C}$ (bisa kurang atau lebih dari $55^{\circ} \mathrm{C}$ ) sehingga respon mencit dapat lebih cepat atau lebih lambat menerima respon dari yang seharusnya. Kemudian kurang telitinya pengamat dalam menghitung respon mencit ketika menerima respon yang diberikan. Faktor internal yang mempengaruhi perbedaan respon mencit bisa juga disebut faktor yang mempengaruhi metabolisme obat atau ekstrak yang diberikan pada mencit, antara lain yaitu genetik atau keturunan, perbedaan umur, makanan, dan penyakit. ${ }^{11}$

Banyaknya faktor yang mempengaruhi tersebut, maka dapat disimpulkan bahwa adanya spesifitas individual terhadap induksi nyeri yang diberikan dan respon mencit terhadap pemberian obat dan ekstrak pun berbeda-beda, sehingga hasil data pengamatan berbeda-beda setiap mencit walaupun dalam kelompok perlakuan yang sama, namun pada keseluruhan rata-rata hasil penelitian ini menunjukkan respon sesuai dengan yang diharapkan dari masing-masing kelompok. Oleh karena itu, perlu menggunakan hewan uji yang lebih banyak dan berasal dari keturunan yang sama untuk kelangsungan penelitian selanjutnya.

\section{SIMPULAN}

Hasil penelitian uji efek analgesik ekstrak etanol daun gedi pada mencit dapat disimpulkan bahwa ekstrak etanol daun gedi memiliki efek analgesik. Efek maksimum dari ekstrak etanol daun gedi didapatkan pada dosis 60 mg/30 g BB.

\section{DAFTAR PUSTAKA}

1. AgroMedia. 273 ramuan tradisional untuk mengatasi aneka penyakit. Jakarta: Agromedia Pustaka, 2008; p.3-4.

2. Nurmalina R. 24 herbal legendaries untuk kesehatan anda. Jakarta: PT Elex Media Komputindo Kelompok Gramedia, 2012; p.1.

3. Mamahit LP. Satu senyawa steroid daun gedi (Abelmoschus manihot L.Medik) asal Sulawesi Utara. Chemistry Progress. 2009;2:33-38.

4. Mamahit LP, Soekamto NH. Satu senyawa asam organik yang diisolasi dari daun gedi (Abelmoschus manihot L.Medik) asal Sulawesi Utara. Chemistry Progress. 2010;3:42-45.

5. Todorwal A, Jain P, Bari S. Abelmoschus manihot Linn: ethnobotany, phytochemistry and pharmacology. Asian Journal of Traditional Medicines. 2011.

6. Jain PS, Todorwal A, Bari S, Surana SJ. Analgesic activity of Abelmoschus manihot extracts. International Journal of Pharmacology 7. 2011;6:716-720.

7. Goodla L, Manubolu $M$, Ravilla $S$, Poondamalli PR. Safety evaluation of the ethanol extract of Ammannia bacifera : assessment of acute and subacute toxicity. Journal of Pharmacy Research. 2010;3(11):2634-2637.

8. Quercetin side effect. Available from: http://lifestyle.iloveindia.com/lounge/querc etin-side-effects-9343.html. Diunduh: 7 Januari 2013.

9. Parker T. Quercetin: a powerfull antihistamin and antioxidant. Available from:

http://ezinearticles.com/?QuercetinAPower fulAntihistamineandAntioxidant\&id=6206 885\&usg=ALkJrhge3yXYUb4_5qfQJKZ 
580 Jurnal e-Biomedik (eBM), Volume 1, Nomor 1, Maret 2013, hlm. 571-580

Eq2f1LBd7Q. Diunduh: 7 Januari 2013.

10. Dewoto HR. Analgesik opioid dan antagonis. Dalam: Farmakologi dan Terapi. Edisi 5. Jakarta : Balai Penerbit FKUI. 2008; h. 210-229.
11. Coleman MD. Factor affecting drug metabolism. Dalam: Human drug and metabolism Edisi 2. UK: Wiley-Blackwell. 2010; h. 159-212. 